\title{
For Hecuba or for Hamlet: Rethinking Emotion and Empathy in the Theatre
}

\section{Amy Cook}

It is true that I am a proselytizer for the work being done at the intersection of the cognitive sciences and the humanities; I can be found on college campuses shaking a copy of The Way We Think (2002) or How the Body Shapes the Mind (2006) and spreading the good word about the importance of deploying research from across the cognitive sciences to previously held beliefs about language and bodies onstage. My aims are not small and my opinions are not meek. There are questions about the great impact that language and performance has on an audience to which I still do not have the answer and yet find more exciting given research in the cognitive sciences. This essay, however, will not be a manifesto, nor will it present clear answers or bold claims. Working in an intersection requires a degree of caution.

I know better than to let that metaphor go unquestioned: interdisciplinary inquiry need not be work and it need not be perilous. If, instead, I describe my project here as playing on the beachfront of theatre and performance studies, watching how the waves of research from the cognitive sciences come in and alter the shoreline, I may open up the field of play, rather than advancing an argument for a kind of work. This is not to suggest that the scholarship is lazy and noncommittal, rather that what I seek to do here is imagine the kinds of sandcastles that could be made on this beach here and now. What if, for example, research on emotions could show us how to rethink our moat building? What if the science of empathy changed how we understood the properties of sand? Research on emotions and empathy, the stock and trade of theatre, poses exciting new questions for the theory and practice of theatre and will shape, dissolve, and reconstitute how we understand what is staged.

The Player blows Hamlet's mind because he can cry and feel emotions for someone he doesn't know as someone he isn't:

$\mathrm{O}$ what a rogue and peasant slave am I!

\footnotetext{
Amy Cook is an assistant professor in the Department of Theatre and Drama at Indiana University, Bloomington. She specializes in the intersection of cognitive science (particularly cognitive linguistics, theories of embodied and embedded cognition, and empathy), and theories of performance and early modern drama. She has published Shakespearean Neuroplay: Reinvigorating the Study of Dramatic Texts and Performance through Cognitive Science, (Palgrave Macmillan, 2010) and essays in Theatre Journal, TDR, SubStance, and several edited volumes. She was a Mellon Fellow in dramaturgy, directing, and dramatic literature at Emory University in Atlanta and received her Ph.D. at University of California, San Diego.
} 
Is it not monstrous that this player here,

But in a fiction, in a dream of passion,

Could force his soul so to his own conceit

That, from her working, all his visage wann'd,

Tears in his eyes, distraction in's aspect,

A broken voice, and his whole function suiting

With forms to his conceit? And all for nothing!

For Hecuba!

What's Hecuba to him, or he to Hecuba,

That he should weep for her?'

Who are we if our bodies, minds, and emotions can change, Proteus-like, so easily? For Hecuba. Further, who is it that is feeling and for whom? Hamlet's almost chiasmatic formulation ("What's Hecuba to him, or he to Hecuba") creates this relational loop-Hecuba to Player and back again — that seems to Hamlet to contain no source for emotion. But the spectator of Shakespeare's play-and Hamlet himself-is struck by the performance of emotion in Hamlet. Hamlet keeps commenting on the seeming of others, with the Player just being the most professional, drawing the spectator's attention to the complicated performance of emotion by Hamlet in Hamlet. The plot, in fact, depends on an understanding of the emotion that does and does not cause action and delay in the play. There is a triangular relationship that is always in effect in performance: the character, the actor, and the spectator. Who is feeling for whom? It is clear to Hamlet that the Player is feeling something in the place of his character for another character and it is clear to us that Hamlet is feeling something for the Player. Just as Hamlet asks about the Player, though, I want to ask how the actor playing Hamlet can feel for Hamlet? What's Hamlet to him or he to Hamlet that he should weep for him? But then, what about me? Why am I moved watching actors feeling for characters feeling for characters in a play I know so well I am mouthing the words? To understand the play is to feel the emotions it evokes - there is no thinking without feeling. But this suggests that emotions are objects, things the playwright places onstage for us to reach out and feel the way we might feel the costume fabric, if the actor got close enough. Before he can understand the connection between the Player and Hecuba - the connection that allows for the transfer of emotion - Hamlet needs to stabilize just what emotion is. If emotion isn't what we think it is, then "transfer" is the wrong word; if emotion isn't an object but is rather a process or a verb, then empathy - the Player's feeling for Hecuba, Hamlet's feeling for the Player, our feeling for Hamlet—needs rethinking too.

Hamlet's concern that the Player weeps for Hecuba while he, with "the motive and the cue for passion," does nothing suggests an interesting relationship between emotions and fiction. Hamlet sees his own reality as more likely to prompt real 
feelings (and, he assumes, actions) and he is outraged that he is not drowning the stage with tears. As Hamlet rages about being dull and "unpregnant of my cause," Shakespeare crams the speech with extra syllables and interrupted lines, contradicting Hamlet's claim that he is "muddy-mettled" and says "nothing":

Who calls me villain, breaks my pate across,

Plucks off my beard and blows it in my face,

Tweaks me by the nose, gives me the lie i' th' throat

As deep as to the lungs-who does me this? ${ }^{2}$

The first three lines above begin with a spondaic and then trochaic feet, shifting the usual rhythm of the iambic foot which stresses the second syllable to a rhythm that stresses the first syllable. The heartbeat rhythm of iambic pentameter calms and regulates the speaker and listener and, thus, irregularity signals emotional content in and of itself. The third line interrupts the iambic rhythm further, shoving extra, unstressed syllables into the line with a trochee in the first, third, and fourth foot. Our ear, trained to hear five stressed syllables per line, must integrate additional information and the actor's speech must speed up to cram the added information in without thoroughly disrupting the music of the language. Hamlet's soliloquy expresses and exposes his own emotions - he has more than the cue for passion here. Moreover, finding himself moved by the Player's performance of emotions, he transforms the "nothing" of his response into a plan. The fiction of the theatre, he decides, is the way to capture the truth of the king's guilt. Emotion, like the "direction" best discovered through "indirection," is best assayed through the performance of emotion. ${ }^{3}$

The performance of emotion is not necessarily the same thing as emotion. The Player performs emotions in reaction to a story of a woman's emotional reaction to her husband's death; while he clearly shows the biological effluvia of emotions - he cries, turns pale, etc. - we do not know whether he experiences the emotions he expresses. Similarly, while Shakespeare expresses Hamlet's emotions in verse and the actor performs Hamlet's emotions in performance, the audience of Hamlet does not know whether or not the actor playing Hamlet actually feels the emotions he conveys. As Denis Diderot says in The Paradox of Acting, and as neuroscientists have shown, the performance need not accurately index the stimulus:

[B] ut what of these touching and sorrowful accents that are drawn from the very depth of a mother's heart and that shake her whole being? Are these not the result of true feeling? Are these not the very inspiration of despair? Most certainly not. The proof is that they are all planned; that they are part of a system of declamation; ... . that, to hit the right mark once, they have 
been practised a hundred times. . . At the very moment when he touches your heart he is listening to his own voice; his talent depends not, as you think, upon feeling, that you fall into the trap. ... All these emotions he has given to you. The actor is tired, you are unhappy; he has had exertion without feeling, you feeling without exertion. ${ }^{4}$

Konstantin Stanislavski, via his nom de maitre Tortsov, explains that it is only through accessing the actor's own emotions that he or she can portray the emotions of the character: "The actor carefully transfers his best qualities onto the stage. The form and setting will vary according to the play, but the actor's human emotions, which run parallel to the feelings of the role, must remain alive. They must not be faked, or replaced by something else, some convoluted actor's trick." 5 Such tricks stain the believability of the actor's performance for Stanislavski. When an actor cries onstage, an audience may or may not notice the seeming virtuosity of the actor capable of crying for the emotions of his character (however he or she manages to do it). Certain biological responses - crying, for example - might call our attention to the body of the actor less than others - an erection, for example. As with Duse's famous blush, blood flow is not expected to be under our conscious control and, therefore, is outside the actor's toolbox. If it cannot be accessed at will, then presumably the actor must experience the necessary emotion in order to evoke the concomitant biological response. This is the basis of inside-out systems of acting: match the inside feeling of the character and the outside of the actor will express the character. But, as Joseph Roach has shown, the science of acting changes to reflect contemporary scientific thinking, so perhaps it is time to interrogate our ideas of emotion in light of current scientific thinking about emotion. ${ }^{6}$

Rhonda Blair has initiated this intellectual and practical project. In her book The Actor, Image, and Action (2008), Blair does not assault twentieth-century acting theory-based primarily on Stanislavski-but neither does she borrow science to "prove" that the creative forces in theatre "had it right." The research of one discipline and methodology is applied to the work of the actor to enrich and enhance what the actor knows and does:

Since acting grows out of our biological being, what we are learning about memory and imagination, and the way emotion, reason, and physicality are ultimately inseparable in the brain's structure and function, has significant implications for how we understand what happens when we act. ${ }^{7}$

Cognitive science allows Blair to rethink acting terms, putting pressure on assumptions and methods that do not cohere with current research and adjusting 
the vocabulary or strategies to take advantage of what we know about how we remember, how we feel, and how we imagine. Although the science of emotion has yielded exciting and important work in the last twenty-five years, there is no universal agreement about how exactly it works or even what it is.

In Descartes'Error (1994), Antonio Damasio defines emotions as a "collection of changes in body state that are induced in myriad organs by nerve cell terminals, under the control of a dedicated brain system, which is responding to the content of thoughts relative to a particular entity or event." thalamus, which is responsible for shunting any potentially alarming information to the amygdala, the body's alarm mechanism. This "down and dirty" pathway of emotion - through the superior colliculus and pulvinar nucleus of the thalamussuggests that stimulus can be reacted to without being "seen" by the visual system or assessed by the cerebral cortex. ${ }^{9}$ Once the sensory cortex has assessed the stimulus, it will send inhibitory or excitatory information to the hypothalamus, which is responsible for sending and receiving messages to and from the rest of the body. The messages involve neurotransmitters and hormones to alter the body state in reaction to the stimulus. These changes or emotional symptoms include sweaty palms, dry mouth, a heart rate change, flushing or pallor, constriction of the stomach, and relaxation or tension of muscles. These responses occur in order to protect as, for example, a change in heart rate will be necessary if the organism needs to flee from the stimulus evoking this response. The hypothalamus monitors the effect of the physical changes on the body and communicates this to the cortex, which continues to assess the information and excite or inhibit the body's reaction via the hypothalamus.

A racing heart, however, could mean panic, rage, or love. Although there may be subtle differences between panic and love in the overall chemical changes in the body, Damasio argues that the primary difference lies in the assessment of the body state by the cerebral cortex. The assessment, which he calls the feeling, is defined as the experience of the emotion in the body juxtaposed to our images, memories, and knowledge of the experience and the stimuli that initiated it. The physical reaction of the body is not specific to a feeling; for the feeling to register to the person the specific mix of bodily changes must be assessed in light of other information. The racing heart and constricted stomach is assessed as love because of the candlelight and the dilated eyes of the man across the table. In another situation, the same experience feels like food poisoning. Whereas emotions can generally be perceived by a bystander, Damasio avers, feelings are internal and private mental states evoked by the physical reaction of emotions.

We may experience emotions as something that happens to us-we are overcome with joy, blinded by rage, etc. - but that does not mean it $i$ s this way. Lisa Feldman Barrett points out that there has been no empirical evidence that emotion is something that exists somewhere. She argues against Damasio, Joseph LeDoux 
and others who argue that "kinds of emotion have specific neural essences" and points out that various studies have failed to find neural correlates for the major emotions. ${ }^{10}$ There may be studies wherein subjects articulate emotions, core and otherwise, but that may just be categorization. Though our experience of emotion may match the Galenic model of humors coursing through the body, altering our perceptions, actions, moods, and so forth, "[c]areful study has determined that we rarely experience things as they actually are. Perception is constructive, even at the most basic sensory levels." constructed, but that the meaning of the stimulus - in relation with a reading of its context - is always a creative act by the perceiver.

Emotions, for Barrett, are not entities that cause an experience of emotion; they are perceptions of our "core affect" defined by Barrett as "the ongoing neurophysiological state that results from evaluations of the (internal and external) environment." ${ }^{\prime 2}$ Although core affect is present at all times, a particular read of the core affect can give rise to an experience of a discreet emotional episode:

Although emotion is experienced as a discrete act, core affect is in constant flow and flux. People are continuously in some state of core affect, constantly moving their faces and their bodies. The possibility pursued here is that the ebb and flow of core affect is parsed into discrete events during the process of perception, and it becomes perceptually bound to the object that is believe [sic] to have caused the feeling in the first place. As a result, a person becomes angry with someone, afraid of something, sad about something. ${ }^{13}$

The core affect, then, is a dynamic yet ever-present state that we experience as emotion in the act of assessing it. If emotion is a verb-the assessing, not the assessed - then we should rethink what an actor does when he/she feels something onstage. Of course, Hamlet's confusion about the relationship between the emotion he is perceiving in the actor and the stated cause of the emotion does not make sense given most twentieth-century acting theory: the Player may be crying while talking about Hecuba, but it doesn't mean he is thinking about or feeling for Hecuba. And yet, the assumption made by many Method actors to follow Stanislavski via Lee Strasberg is that the emotion is incited by the story; imagine Aunt Polly and talk of Hecuba. To imagine a core affect that is present always already and emotion as the act of assessing it is to open the possibility that we are overcomplicating emotion onstage. If - instead of being an object that hurls itself from a person or environment onto our amygdala, is experienced with backstory and future story in the brain, and then elicits an outward show — emotion is actually a storyless jelly that affords and shapes our actions, then an emotion onstage will be something you 
do, like a dance, rather than something you have, like a prop.

While Barrett's explanation sees emotions as individual perceptions of internal states, for others, emotions are primarily social. Paul Griffiths and Andrea Scarantino see emotions as socially situated interpersonal strategies that are always engaged in relationship with or "scaffolded" by the environment. ${ }^{14}$ One's emotions here are always in such a tight feedback loop with the environment that it is not always clear which is which. Emotions, for Griffiths and Scarantino, are dynamic scenes:

In traditional models of emotional appraisal, the organism receives information from the environment and uses it to determine the emotional significance of the situation that confronts it. In contrast, the situated perspective envisages organisms 'probing' their environment through initial emotional responses, and monitoring the responses of other organisms to determine how the emotion will evolve. ${ }^{15}$

This give and take of emotion understands the individual as always situated within a dynamic system; emotions here are communicative and socially performed: "For society to function smoothly, individuals must have the right emotions at the right times, and it is not left to individual psychological processes to ensure that this occurs. ${ }^{16}$ We have wedding ceremonies, funerals, and performances of Hamlet because we need practice to learn how to navigate the emotional reactions required of us.

The socially situated perspective on emotion is similar to theories of emotional contagion. Elaine Hatfield, John Cacioppo, and Richard Rapson see emotions relationally, in that they can be caught and spread and are determined by stimulus from the outside or the inside. In Emotional Contagion, they argue that "an important consequence of emotional contagion is an attentional, emotional, and behavioral synchrony that has the same adaptive utility (and drawbacks) for social entities (dyads, groups) as has emotion for the individual." ${ }^{17}$ What this suggests is that we are not separate and contained individuals; we are porous and seeping. According to emotional contagion theory, we "synchronize facial expressions, vocalizations, postures, and movements with those of another person and, consequently . . . converge emotionally." ${ }^{\prime 18}$ Based on the speed with which their studies show that this occurs, this is not a conscious attempt to reflect or match the feelings of another but rather an automatic mirroring. Here, emotions are a series of relational signals between and within bodies, since to experience and understand an emotion (of self or other) requires embodied imitation. Although their work in this area has continued, this book was written in 1994, two years before mirror neurons were discovered in monkeys. Research since then has shown that humans as well as monkeys have a neural mirroring system that may facilitate shared emotional states. This automatic 
embodied imitation (at least as far as some small number of cells is concerned) suggests that our knowledge of the experience and intentions of others comes to us immediately, that a motivation for collaboration comes from deep in our cells, and social emotional synchrony or understanding is a bottom-up as well as a topdown process. The science of emotion, however, continues to grow and change. Perhaps the most important thing to note for theatre scholars is the metaphor used to understand emotions. Are they things that can be "caught"? Particular body states? Perturbations in a dynamic social system? How we imagine the subject, of course, defines how we can imagine new ways of studying it. One thing that is clear - though it must continually be restated - is: emotion is a fundamental and instantaneous part of any and all cognitive assessment and interpretation. Again, there is no interpretation of an event, text, or image that does not involve emotion, sensation, and memory. Understanding emotions, then, is not just important in trying to figure out how to convey them to an audience, it is important because it is part of how we know what we know.

\section{Empathy}

First articulated in the nineteenth century as a way of understanding how particular paintings and sculptures can impel feeling - how we "feel into" a Romantic landscape painting, for example, or characters in a Victorian novelempathy has become an investigative focus in cognitive science, psychology, philosophy, ethics, and narratology, as well as aesthetics. ${ }^{19}$ Some define empathy as sharing the affective state of another, others insist it includes perspective-takingunderstanding the affective state from the other person's point of view - and some add that it includes a desire to do something with or for the other person. Daniel C. Batson outlines eight different concepts that have all been labeled "empathy," distinguishing, for example, "Imagining How Another is Thinking and Feeling" (Concept 5) from "Imagining How One Would Think and Feel in the Other's Place" (Concept 6) ${ }^{20}$ When fMRI machines register firings in particular parts of the brain of subjects seeing a knife fall toward someone's foot, it is called empathy. When a character onstage cries because of an experience of his character, or the audience cries watching this performance, we call it empathy. When we go to the Holocaust Museum and feel moved at the artifacts of genocide, we call it empathy. Because Judge Sonia Sotomayor has had "experience being tested by obstacles and barriers, by hardship and misfortune" she will bring empathy to the Supreme Court. ${ }^{21}$ If empathy is something I can feel for a character, experience neurally and preconsciously, and adjust for social, judicial, ethical, and historical contexts, it qualifies as a vexed term. ${ }^{22}$ Theatre scholars should attend to the interdisciplinary scrum over empathy because social emotional contagion is our stock and trade.

In her contribution to David Román's collection of essays by theatre and performance scholars on "tragedy" in the immediate aftermath of September 11, Jill 
Dolan reports empathizing "so deeply" with the passenger on the plane or the World Trade Center office worker who clutched her purse to her chest as she jumped out of the burning tower, that "after the first several days of obsessive viewing, listening, and reading, I weaned myself away, immersed myself in the remains of the rest of my life, just so that I . . could protect myself for a future I now question exists." She then asks, "Has performance trained me for such painful empathy?" 23 This is an excellent question - certainly one that would, if answered in the affirmative, justify a tremendous amount of federal support of the arts - and one that requires some clarification around what we want and need "empathy" to mean and what we are pointing to when we speak of a performance that could elicit the kind of reaction Dolan (and many others) had watching the bodies fall.

Empathy is often thought of in terms of that 90s cliché: "I feel your pain." And, indeed, research on nociception has produced the clearest indication that we do feel one another's pain. Lying in an fMRI machine, a subject is shown a video of a person cutting a carrot and then accidentally cutting her own finger. Images of the brain at that moment, the moment the knife strikes the finger, show cells firing in the region of the brain that registers pain. Pain perception involves some of the neurons responsible for registering pain felt by the self and, thus, knowing the other person is in pain means, on some level, feeling the pain they are in. (Again, cognition and interpretation is a full-bodied affair.) This is extraordinary information for people interested in performance and spectatorship. Without going more in depth into pain perception research or some of the qualifications, ${ }^{24}$ if all I allow in right now is the idea that the perception of pain is also the experience of pain, I must acknowledge that the body and the emotions are inseparable from cognition and that the subject and object might not be where I begin but rather where I end. Before there is you or me, the knife and the carrot, there is the pain.

Although studies have revealed partial overlap in cell excitation in seeing pain and experiencing pain, there is not a complete mirroring and an appraisal of the context ("my thumb is not actually in danger") quickly inhibits further cell firing. Even though I may feel your pain, I do not forget that I am me and you are you. The recognition that the aversive act is not happening to the self, but to the other, is what makes it "empathy" and not "pain." The "painful empathy" that Dolan experienced is not conducive to empathetic acts: if it hurts to be aware of it, we turn away from the aversive stimulus, conflating the stimulus hurting them with the stimulus hurting us. Pivotal to empathy, then, is not a merging of self and other but the recognition of separation. As Decety and Lamm point out,

Self-awareness is a necessary condition for making inference about the mental states in others. Therefore, 'agency' is a crucial aspect for successfully navigating shared representations between self and other. Further, agency plays a pivotal role in 
cognitive development, including the first stage of self-awareness .... Indeed, the ability to recognize oneself as the agent of a behavior is the way one builds an entity independent from the external world. In the case of empathy, affective sharing must be modulated and monitored by the sense of whose feelings belong to whom, and thus, agency is a crucial aspect that enables a selfless regard for the other rather than a selfish desire to escape aversive arousal. ${ }^{25}$

If you are really in pain, you do not want me to feel your pain. You want me to feel my own power to stop your pain.

Pain is subject/object neutral; empathy is a relationship. While empathy may begin with an experience of shared pain, it does not end there. Empathy requires a distinction between self and other and also the ability to take on the perspective of the other in order to assess the causes and circumstances of the pain. As Frederique de Vignemont and Tania Singer argue, a definition of empathy should include a number of qualifications: shared affect, an awareness of the other person's perspective, and the knowledge that the other person is the cause of one's affective state. This is why emotional contagion, for them, is not empathy, because a baby can cry when it hears another baby cry but not know that the other is the source of his upset. To have empathy is to understand the story of the pain.

Pain always has a story. The experience of pain may destroy language, context, and the world, as Elaine Scarry has argued, ${ }^{26}$ but the perception of that experience requires a remaking of the world capable of creating that pain. All pain is not created equal. In one study, subjects played a series of games with confederates, some of whom played fairly and some of whom did not. When the male subjects then witnessed the unfair players being pricked with a pin, their brains showed an absence of empathic activity and actually showed activity in areas associated with pleasure. ${ }^{27}$ A study by Lamm et al. included subjects' assessments of the pain level of the other. They found that the subjects who were asked to imagine themselves going through the painful experience they were watching the other undergo perceived the pain to be greater than those asked to imagine that it was another in pain. Additionally, subjects who were told that the person was undergoing successful treatment for a health problem perceived the pain to be less than those told the treatment was unsuccessful. The scientists conclude, "[B]oth bottom-up (automatic) and top-down (controlled) processes interact to produce the experience of empathy. Knowledge about the context in which the pain experience occurs provides important clues to the role of top-down cognitive appraisal in the regulation of the vicarious affective pain reaction." ${ }^{28}$ Empathy means that we feel it, we see it, and we contextualize it.

And usually we care about it. Empathy is not a value-neutral term: we assume that to have empathy for another person is a good thing, and that if someone feels 
the pain of the other person he or she will also want to alleviate that pain. But if a person witnesses another person in pain and does not want to alleviate it, does he or she not have empathy? Research on psychopaths suggests that they lack the kind of mirroring found in others when witnessing another in pain. In fact, they do not feel anything particularly deeply and yet they can be incredibly good at faking the emotions their social environments expect of them. Their own lack of feeling, however, impacts their ability to perceive emotions in others. They have trouble detecting fear in the voice or facial expressions of others and "miss the emotional nuances of language" and "have trouble understanding metaphors - for example, they are more likely than others to judge as negative the phrase 'Love is an antidote for the world's ills." 29 The rest of us understand that this phrase is hopeful because we feel it; psychopaths cannot understand because they cannot feel. On the other hand, feeling is not the antidote to suffering. Feeling another's pain does not necessarily mean we wish to do something to alleviate that pain, or that we are interested in alleviating anything other than our own distress at the perception of pain. Batson points to research that "parents who are at high risk of abusing a child are the ones who more frequently report distress at seeing an infant cry" while parents at low risk do not report distress but rather "otheroriented feelings - sympathy and compassion." ${ }^{30}$ Similarly, empathy would be a very dangerous quality in an emergency room doctor; such doctors must be very good at turning off or disinhibiting empathetic responses to the sight of the pain of others so that they could take the actions necessary to alleviate the pain-even when it means causing more pain temporarily.

So, what about Iago? He could not direct the psychological maelstrom that swirls around Othello if he was not particularly adept at knowing what Othello would see and feel from his perspective. ${ }^{31}$ Being able to read and respond to the emotional signals of others seems like a prosocial skill. A recent headline in The New York Times failed to shock the class-conscious by reporting that "The Rich Lack Empathy." Those who reported being wealthy or more upper class were not as good at reading the expressions of emotion on the faces of strangers. The researchers suggest that, perhaps, having an expertise in the reading of social cues is less valuable to the wealthy, since they do not need to rely as much on the "kindness of strangers." ${ }^{32}$ Those whose survival is more dependent on the help or allegiance of their neighbors are better able to navigate the social-emotional world around them. In an interesting follow-up experiment, when subjects were told to imagine themselves relative to the very rich, their ability to judge emotional expressions improved. Empathy is not, then, genetically coded to class or bank account balance, but rather it is dependent upon the story subjects tell themselves about their social standing and power. This suggests, though, that it is a skill that can be developed which seems counter to theories of it being automatic or neurological. We speak of empathy as if it were a virtue, an emotion, a reflex, and a power of imagination, 
but it cannot be all of these things at the same time.

To feel for a character onstage is very different from feeling for another person in a laboratory; theatre and performance happens with and for a group. We do not feel in isolation in the theatre, we share the experience, perspective, and emotions with other people in the audience. Moreover, the audience watches the dynamics between characters onstage and there are always competing claims for our empathy. If empathy was simply (or even mostly) a case of embodied imitation leading to a shared affective state, at the end of Hamlet we would not be able to decipher between our feelings for Gertrude, Laertes, Hamlet, or Claudius. ${ }^{33}$ They all die, they all perform pain, but it is our sweet prince that receives the lion's share of our emotional connection. Shakespeare can coax spectators to feel empathy for a misshapen murderous king like Richard III, but an fMRI experiment cannot handle this level of complexity. ${ }^{34}$

Fritz Breithaupt combines empathy research from the neurosciences with narrative theory to posit that empathy involves side-taking in a three-person dynamic. He argues that empathy must be studied not within a two-person scene but in a more complicated social scene: "Most theories thus portray empathy as a particularly close observation in a two-person scene that also takes into account the intentions and emotions of the other person. . . . [I]t seems that this focus on observation within a two-person model may be too narrow for the most social animal." 35 His three-person model of empathy posits that because empathy is generally stronger when we perceive causality - this pain was caused by that person or event - it "results from taking sides in a three-person scene." ${ }^{36}$ For Breithaupt, importantly, we feel empathy not in order to facilitate side-taking, but rather as a result of taking sides: "[A]fter the quick side-taking, empathy may come in and maintain the quick decision. Empathy would then be a secondary act, a consequence of taking sides. I feel with the other because I have decided for him. ${ }^{\prime 37}$ Empathy presupposes side-taking. It would not be efficient to immediately feel (or internally mirror the emotions of) the four people dying onstage and then decide on whom to focus your empathy. That decision has been made and the emotional reaction follows. ${ }^{38}$

This formulation describes a cause-and-effect chain that suggests linearity, though, and I am persuaded by arguments that cognition is a dynamic system and that finding a "first" and then a "next" is less helpful than appreciating the complicated simultaneity of it. ${ }^{39}$ Understanding why Hamlet is moved by the Player and why we are moved by Hamlet is a far more complicated emotional event than watching a knife fall on a thumb or a person's face contort in pain. Theatre scholars need emotion researchers to study the dynamics of emotion in the theatre, not just in the laboratory. Nonetheless, like Hamlet, scientists are trying to understand "What's Hecuba to him, or he to Hecuba, / That he should weep for her?" and what they are learning - about the immediacy of pain perception and also its mediation by 
contextual information - can inform how scholars imagine the empathetic potential of theatre. Understanding the details of Hecuba and Priam's story is importantthe Player cannot deliver his speech without knowing it - but it is not this story that moves Hamlet. It is, rather, the way in which the Player embodies the story. Similarly, the Player would not produce emotional effluvium simply hearing the story; he has to embody the story. It is in his telling it, not Hamlet's telling of it in order to prompt him (“One speech in't I chiefly lov'd, 'twas Aeneas' tale to Dido, and thereabout of it especially when he speaks of Priam's slaughter" ${ }^{\prime 4}$ ) that brings about the emotional reaction that causes Hamlet's emotional reaction. Shakespeare uses metatheatre here to point out not only the irrationality of caring but also the inevitability of caring. In Hamlet, Shakespeare stages watching, and the relationship between the two is where the comedy - and the pathos - is located. Shakespeare does not present the Player's speech in order to move the audience of Hamlet; he presents Hamlet's spectatorship of the speech in order to move the audience of Hamlet. In this complex system, we are moved by a spectator's articulation of the power of witnessing.

\section{Conclusion}

The spectator watches Hamlet watching the Player talk about Hecuba. Who's feeling what for whom? And what is the nature of this "feeling?" Damasio defines emotions as changes in body state and notes that spectators can perceive these emotions, but not the feelings (mediated by context, memory, story) that are conscious only to the individual experiencing them. For Barrett, emotions are not objects but an evaluation event that creates a story (subject, verb, object); and, for Griffiths and Scarantino, emotions are a product or element of the environmentthey are socially situated strategic probes. Emotional contagion research suggests that we are always, to some degree, emotionally porous and that we converge emotionally. Whatever the case may be, the incredibly exciting developments in the science of emotion suggest that our experience of the emotions of the performance is inseparable from an interpretation of what the event was. Central to Hamlet's concern, and ours, is the biological changes evident during the Player's performance. Furthermore, if emotion is indeed contagious, then theatrical representation can "catch" our consciousness - we are always aware of the emotional environment. And, if theories of situated emotion are correct, we are always contributing to this environment, meaning that the emotional performance of each individual audience is relevant to the analysis and interpretation of each night's performance. This is why, perhaps, actors are right to talk about the "feeling in the house." Hamlet's experience calls on the sciences to ask the questions more central to our lived experience than the knife and the carrot: what happens when it is not a dyad in a lab?

For Jill Dolan, "painful empathy" led to a renewed hope for theatre: 
If our imaginations can lead us to profound, performative empathy, I believe ever more strongly that the space of performance must be harnessed to imagine love instead of hatred, to create hopeful fictions of meaningful lives instead of senseless deaths. I need to believe that theorizing and documenting, witnessing and creating performance will continue to grace our lives with meaning, generosity, understanding, and memory, however provisional and fleeting. I know that performance couldn't stop the woman with the purse from jumping, but I hope it can memorialize and make sense of her actions. ${ }^{41}$

Based on research in cognitive science, Rhonda Blair finds a similar utopian place for theatre and performance in our lives:

I find it powerful that imagination, which fundamentally is about the organism having pictures of itself in different situations and contexts in order to know how to negotiate its environment as well as possible, happens not only consciously, but also extensively and richly below the level of consciousness, so that it might be possible to view what we are doing when we're making theatre as helping the viewers' bodies imagine themselves inside the stories we tell. ${ }^{42}$

Like Dolan, Blair, and Hamlet, I believe that what happens to us sitting in the theatre, watching a play is profound and has earth-shattering potential. I am still not sure how I want to define empathy in the theatre. I want it to include the visceral reaction spectators can sometimes feel in response to a performance- the mirroring across the fourth wall — but I do not have an answer for why this mirroring is both automatic and selective. I know that watching people put on a play operates as a cognitive perspective manipulator - it entails the taking of alternate perspectives and I want to believe that this encourages prosocial behavior. But what the science of emotion and empathy leads me to question is if it looks like what I think it looks like. In other words, if making me feel is not so very difficult (if you can do it with a video while I lie in an fMRI machine, you should be able to do it with live people, stories, music, and lighting), then perhaps what is powerful in the theatre is feeling agency and self. Breithaupt points out that empathy relies just as much on its lack as it does on its presence: "[E]mpathy, the understanding of others, only comes to pass because our emotional attention towards others is mostly jammed, blocked, and filtered. Without such a (partial) blockade we would live in a world of constant loss of perspective, in which we would involuntarily take over the perspectives of not only all the people with whom we came in contact, but also 
those of animals, mythical creatures, and perhaps even objects." ${ }^{\text {"3 }}$ So, perhaps, theatre helps us navigate the blockade. Shakespeare does not stage the Hecuba speech to show Hamlet something about Hecuba; Hamlet's reaction is about Hamlet. While Hamlet's verse unveils the kind of mirrored pain perception of an fMRI scan, Shakespeare shows us the character working through the pain to gain an understanding of his situation and finally grasping some degree of agency; he puts on a play. Hamlet is confused by the lack of connective tissue between himself, the Player, and Hecuba that would allow the kind of emotional seepage to occur, and so much of our acting and theatre theory aims to understand what it is that the Player must do inside to empathize with Hecuba in order to move Hamlet. But the cognitive sciences might lead us to another question: it is not the connecting of the three that theatre should aim at — that is always already there — but rather the separating of the three.

So, back on my interdisciplinary beach, what I notice is that the scientific waters changing this particular beach are different than the scientific waters that washed over the beach of the Moscow Art Theatre or the Berliner Ensemble. Ideas of emotion - whether in the lab or in the theatre-impact the theatre we are interested in making and so, perhaps, we can see a different attitude toward emotions onstage in contemporary theatre. The sandcastles we can make here are exciting - there are garrets shaped from visual perception research, moats filled with Dynamic Systems Theory, and towers of conceptual blends. I want a space where the questioning itself can dissolve the categories of the object under investigation, where anything can be. I want to re-perform inquiry itself.

\section{Notes}

1. This and all subsequent quotes from Hamlet are from The Riverside Shakespeare: The Complete Works, $2^{\text {nd }}$ ed., ed. Frank Kermode (Boston, MA: Houghton Mifflin, 1997); 2.2.550-60.

2. Hamlet 2.2.572-75.

3. Polonius sends Reynaldo to spy on Laertes in France, asking him to spread lies about Laertes in order to find out if someone contradicts him — getting directions from the indirections of Reynaldo's tales. For a longer discussion of this as it relates to the rest of the play and the idea of theatre Hamlet expresses to the players, see Cook, Shakespearean Neuroplay: Reinvigorating the Study of Dramatic Texts and Performance through Cognitive Science, (New York: Palgrave Macmillan, 2010) 71.

4. Denis Diderot, The Paradox of Acting (New York: Hill and Wang, 1957) 19.

5. Konstantin Stanislavski, An Actor's Work: A Student's Diary, trans. Jean Benedetti (New York: Routledge, 2010) 209.

6. See Joseph Roach, The Player's Passion: Studies in the Science of Acting (Ann Arbor: U of Michigan P, 1993).

7. Rhonda Blair, The Actor, Image, and Action: Acting and Cognitive Neuroscience (New York: Routledge, 2008) xii. In her article for $T D R$, Blair continues this investigation into empathy, to which I will return.

8. Antonio Damasio, Descartes' Error: Emotion, Reason, and the Human Brain (New York: Avon, 1994) 139.

9. In their introduction to Emotion and Consciousness (New York: Guilford, 2005), Barrett, Niedenthal, and Winkielman note that "this mechanism mediates affective reactions to a stimulus even before it is registered in consciousness, and allows people with blindsight to code the affective significance of things they cannot consciously see" (6). Taking a hike once, I jumped back before seeing 
the rattlesnake. I perceived the movement and that information was acted on before my visual system said: "snake!" In this way, my jumping back is as much the "meaning" of what I saw as the word I found-"snake!"- to "label" what I just saw.

10. Lisa Feldman Barrett, "Feeling Is Perceiving: Core Affect and Conceptualization in the Experience of Emotion," Emotion and Consciousness, eds. Lisa Feldman Barrett, Paula M. Niedenthal and Piotr Winkielman (New York: Guilford, 2005) 260.

11. 262 .

12. 264 .

13. 268.

14. Paul Griffiths and Andrea Scarantino, "Emotions in the Wild: The Situated Perspective on Emotion," The Cambridge Handbook of Situated Cognition, ed. Philip Robbins and Murat Aydede (New York: Cambridge UP, 2009) 437.

15. 438.

16. 445 .

17. Elaine Hatfield, John T. Cacioppo, and Richard L. Rapson, Emotional Contagion (Cambridge: Cambridge UP, 1994) 5.

18. 5 .

19. In addition to other sources cited herein, some useful interdisciplinary work on empathy include: David Freedberg and Vittorio Gallese, "Motion, Emotion and Empathy in Esthetic Experience," Trends in Cognitive Sciences 11.5 (2007): 197-203; Claus Lamm, C. Daniel Batson, and Jean Decety, "The Neural Substrate of Human Empathy: Effects of Perspective-Taking and Cognitive Appraisal," Journal of Cognitive Neuroscience 19.1 (2007): 42-58; Decety and Lamm, "Human Empathy through the Lens of Social Neuroscience," The Scientific World Journal (2006): 1146-163; Nancy Sherman, "Empathy and the Imagination," Midwest Studies in Philosophy, XXII (1998); Frans de Waal, "Putting the Altruism Back into Altruism: The Evolution of Empathy," Annual Review of Psychology 59 (2008): 279-300; Greiner, Rae, "Sympathy Time: Adam Smith, George Eliot, and the Realist Novel," Narrative 17.3 (October 2009): 291-311; and Suzanne Keen, “A Theory of Narrative Empathy," Narrative 14.3 (October 2006): 207-36; David Sussman, "What's Wrong with Torture?" Philosophy and Public Affairs 33.1 (2005): $1-33$.

20. C. Daniel Batson, "These Things Called Empathy: Eight Related but Distinct Phenomena," The Social Neuroscience of Empathy, eds. Jean Decety and William Ickes (Cambridge, MA: MIT, 2009): 3-13.

21. The fight over Sotomayor's judicial appointment provides a stunning example of the confusion over empathy in the social and political arena. For conservatives, this suggests emotional decisionmaking - even "menstrual" - while for progressives this suggests the wisdom of a "wise Latina." For an interesting discussion of the debate from a cognitive linguistic perspective, see George Lakoff, "Empathy, Sotomayor, and Democracy: The Conservative Stealth Strategy," The Huffington Post, May 30, 2009. Accessed October 15, 2010. Lakoff quotes G. Gordon Liddy as saying, "Let's hope that the key conferences aren't when she's menstruating or something, or just before she's going to menstruate. That would really be bad. Lord knows what we would get then."

22. Jonathan Levy's essay "A Note On Empathy" gives a history of the term and argues that we need new terms to clear up the current ambiguities (Levy, "A Note on Empathy," New Ideas in Psychology 15.2 [1997]: 179-84).

23. Jill Dolan, "A Forum on Theatre and Tragedy in the Wake of September 11, 2001," Theatre Journal 54.1 (2002): 106. Some of the other authors are: Diana Taylor, Una Chaudhuri, W. B. Worthen, Jennifer DeVere Brody, Harry J. Elam, Jr., Sue-Ellen Case, Jill Lane, Richard Schechner, and Marvin Carlson.

24. As Jean Decety points out, sensorimotor resonance is not the same thing as empathy and care should be taken with the extrapolations made from some of the research on the mirror neuron system (MNS) and empathy. There is clear evidence that the MNS is involved in motor resonance, but the research showing that it is involved in emotional resonance is much more problematic. There is research that shows that observing facial expressions of emotions elicits self-reported mood change, but there have been problems, he says, with some of the work using fMRIs looking for overlap in excitation between observation and experience: "[M]any studies interpret any hemodynamic response in the IFG [inferior frontal gyrus] and anterior intra parietal sulcus as being due to mirror neuron activity, as if the regions only consisted of mirror neurons, and thus both grossly ignoring that mirror neurons in the monkey account for only a small minority of the cell population" (2). He does support work (conducted in part by him) that has found an overlap in experience and observation of emotion and sees this as shared neural circuits, but he even qualifies this, noting that since pain is never totally separate from the system responsible for avoidance and defense, perhaps the activation in the witness is about preparing for flight or for fight. See Decety, "To What Extent Is the Experience of Empathy Mediated by Shared 
Neural Circuits?" Emotion Review (2010): 1-4.

25. Jean Decety and Claus Lamm, "Human Empathy through the Lens of Social Neuroscience," The Scientific World Journal (2006): 1154.

26. Elaine Scarry, The Body in Pain: The Making and Unmaking of the World (New York: Oxford UP, 1985). Scarry argues, "Physical pain does not simply resist language but actively destroys it, bringing about an immediate reversion to a state anterior to language, to the sounds and cries a human being makes before language is learned" (4). The work required to put words to pain is, for Scarry, what makes the world, creates the artifacts of human-ness.

27. The difference in empathic response between witnessing the pain of the fair player versus the unfair player was not present in women subjects. See the citation in Frederique de Vignemont and Tania Singer, "The Empathic Brain: How, When and Why?" Trends in Cognitive Sciences 10.10 (October 2006): 437. For the original study see T. Singer, et. al., "Empathic Neural Responses Are Modulated by the Perceived Fairness of Others," Nature 439 (2006): 466-69.

28. Claus Lamm, C. Daniel Batson, and Jean Decety, "The Neural Substrate of Human Empathy: Effects of Perspective-Taking and Cognitive Appraisal," Journal of Cognitive Neuroscience 19.1 (2007): 56.

29. Kent A. Kiehl and Joshua W. Buckholtz, "Inside the Mind of a Psychopath," Scientific American Mind (September/October 2010): 25.

30. Batson, "These Things Called Empathy: Eight Related but Distinct Phenomena" 9.

31. Perhaps he is a psychopath. Psychopaths may not be able to perceive the emotions of others, but "some studies show that after receiving group therapy in prison, psychopaths are more likely to commit new crimes than if they had received no treatment at all. Listening to others bare their soul is clearly not a good strategy: psychopaths are notoriously good at learning and exploiting the weakness of others." See Kiehl and Buckholtz, "Inside the Mind of a Psychopath" 28.

32. This would certainly explain why poor Duke of Buckingham fails to notice that Richard III is "not in the giving vein" and that he should return at another time to seek the removables Richard had previously promised him; 4.2.116.

33. And what about the confession scene? Claudius, kneeling in prayer, begs for forgiveness alone onstage. Hamlet comes in and raises his dagger to do it pat. He does not do it, for a series of reasons that generally fail to persuade undergraduate readers. In that moment, dagger raised, with whom do we empathize?

34. That also reminds us that it was not meant to either, and we should be careful about overextending highly specific scientific research into the theatrical event.

35. Fritz Breithaupt, "A Three-Person Model of Empathy," Emotion Review, forthcoming, 11. He goes on to suggest that not only must we study empathy in social scenes, but that, perhaps, social scenes are impossible without empathy.

36. 15 .

37. 14.

38. This may happen below the level of consciousness and/or it may occur too fast to assess which comes first.

39. See John Lutterbie, Toward a General Theory of Acting: Cognitive Science and Performance (New York: Palgrave Macmillan, 2011).

40. Hamlet 2.2.445-48.

41. Dolan, "A Forum on Theatre and Tragedy in the Wake of September 11, 2001" 106-07.

42. Rhonda Blair, "Cognitive Neuroscience and Acting: Imagination, Conceptual Blending, and Empathy," TDR 53.4 (2009): 102.

43. Breithaupt, "A Three-Person Model of Empathy" 7. 
